\title{
A Mutant Prion Protein Sensitizes Neurons to Glutamate- Induced Excitotoxicity
}

\author{
Emiliano Biasini, ${ }^{1,3,4 \star}$ Ursula Unterberger, ${ }^{1 \star}$ Isaac H. Solomon, ${ }^{1}$ Tania Massignan, ${ }^{1,3,5}$ Assunta Senatore, ${ }^{3,4}$ Hejiao Bian, ${ }^{1}$ \\ Till Voigtlaender, ${ }^{6}$ Frederick P. Bowman, ${ }^{1}$ Valentina Bonetto,,${ }^{3,5}$ Roberto Chiesa, ${ }^{3,4}$ Jennifer Luebke, ${ }^{2}$ Paul Toselli, ${ }^{1}$ \\ and David A. Harris ${ }^{1}$ \\ Departments of ${ }^{1}$ Biochemistry and ${ }^{2}$ Anatomy and Neurobiology, Boston University School of Medicine, Boston, Massachusetts 02118 , ${ }^{3}$ Dulbecco Telethon \\ Institute and Departments of ${ }^{4}$ Neuroscience and ${ }^{5}$ Biochemistry and Molecular Pharmacology, Mario Negri Institute for Pharmacological Research, I-20156 \\ Milan, Italy, and ${ }^{6}$ Institute of Neurology, Medical University of Vienna, A-1097 Vienna, Austria
}

Growing evidence suggests that a physiological activity of the cellular prion protein $\left(\operatorname{PrP}^{\mathrm{C}}\right)$ plays a crucial role in several neurodegenerative disorders, including prion and Alzheimer's diseases. However, how the functional activity of $\operatorname{PrP}^{\mathrm{C}}$ is subverted to deliver neurotoxic signals remains uncertain. Transgenic (Tg) mice expressing PrP with a deletion of residues 105-125 in the central region (referred to as $\Delta \mathrm{CR} \operatorname{PrP})$ provide important insights into this problem. $\operatorname{Tg}(\Delta \mathrm{CR})$ mice exhibit neonatal lethality and massive degeneration of cerebellar granule neurons, a phenotype that is dose dependently suppressed by the presence of wild-type PrP. When expressed in cultured cells, $\Delta$ CR PrP induces large, ionic currents that can be detected by patch-clamping techniques. Here, we tested the hypothesis that abnormal ion channel activity underlies the neuronal death seen in $\operatorname{Tg}(\Delta \mathrm{CR})$ mice. We find that $\Delta \mathrm{CR}$ PrP induces abnormal ionic currents in neurons in culture and in cerebellar slices and that this activity sensitizes the neurons to glutamate-induced, calcium-mediated death. In combination with ultrastructural and biochemical analyses, these results demonstrate a role for glutamate-induced excitotoxicity in PrP-mediated neurodegeneration. A similar mechanism may operate in other neurodegenerative disorders attributable to toxic, $\beta$-rich oligomers that bind to $\operatorname{PrP}^{\mathrm{C}}$.

\section{Introduction}

Although the notion that prion propagation involves conformational conversion of the cellular prion protein $\left(\operatorname{PrP}^{\mathrm{C}}\right)$ into the scrapie prion protein $\left(\mathrm{PrP}^{\mathrm{Sc}}\right)$ is now widely accepted, the mechanism by which prions cause neurodegeneration is still uncertain (Caughey and Baron, 2006; Harris and True, 2006; Aguzzi et al., 2007). Multiple lines of evidence indicate that the presence of functionally active $\operatorname{PrP}^{\mathrm{C}}$ on the cell membrane is required for $\mathrm{PrP}^{\mathrm{Sc}}$ molecules to exert their neurotoxic effects (Brandner et al., 1996; Mallucci et al., 2003, 2007; Chesebro et al., 2005). Recently,

Received July 17, 2012; revised Nov. 20, 2012; accepted Dec. 6, 2012.

Author contributions: E.B., U.U., I.H.S., T.M., T.V., V.B., R.C., J.L., P.T., and D.A.H. designed research; E.B., U.U., I.H.S., T.M., A.S., H.B., T.V., F.P.B., and P.T. performed research; J.L. contributed unpublished reagents/analytic tools; E.B., U.U., I.H.S., T.M., A.S., T.V., P.T., and D.A.H. analyzed data; E.B., U.U., and D.A.H. wrote the paper.

This work was supported by National Institutes of Health (NIH) Grants NS040975 and NS052526 (D.A.H.) and AG00001 and AG025062 (J.L.), Telethon Italy Grants TCR08005 (R.C.) and TCR08002 (V.B.), and a fellowship from the Antonio Carlo Monzino Foundation (E.B.). U.U. was supported by Erwin Schroedinger Fellowship J2840 from the Austrian Science Fund. I.H.S. was supported by NIH Predoctoral Fellowship NS063547 and the Medical Scientist Training Program at Washington University (St. Louis, M0) (NIH Grant T32GM007200). V.B. and R.C. are Associate Telethon Scientists (Dulbecco Telethon Institute, Telethon Italy). We thank Joe Amatrudo in the Leubke laboratory for advice and technical assistance with patch clamping. We also thank Jorge De Castro for mouse maintenance and genotyping and Nada Husic for lentiviral preparation. Lentiviral constructs were created by the Hope Center Viral Vectors Core at Washington University, which is supported by National Institutes of Health Neuroscience Blueprint Core Grant P30 NS057105.

${ }^{*}$ E.B. and U.U. contributed equally to this work.

The authors declare no competing financial interests.

Correspondence should be addressed to Emiliano Biasini or David A. Harris, Department of Biochemistry, Boston University School of Medicine, 72 East Concord Street, Boston, MA 02118. E-mail: biasini@bu.edu, daharris@bu.edu. DOI:10.1523/JNEUROSCI.3406-12.2013

Copyright $\odot 2013$ the authors $\quad 0270-6474 / 13 / 322408-11 \$ 15.00 / 0$
$\operatorname{PrP}^{\mathrm{C}}$ has also been shown to mediate the toxicity of other pathological protein aggregates, including oligomers of the amyloid $\beta$ $(\mathrm{A} \beta)$ peptide, which are associated with Alzheimer's disease (Laurén et al., 2009; Balducci et al., 2010; Chen et al., 2010; Resenberger et al., 2011). Collectively, these studies suggest that the normal function of $\operatorname{PrP}^{\mathrm{C}}$ could be corrupted by several kinds of $\beta$-rich protein oligomers to generate neurotoxic effects (Gunther and Strittmatter, 2010; Biasini et al., 2012a).

As a way of elucidating the neurotoxic potential of $\mathrm{PrP}^{\mathrm{C}}$, we have been studying an artificial mutant $\operatorname{PrP}$ (designated $\Delta \mathrm{CR}$ ) that carries a deletion of 21 aa in the conserved central region of the protein (residues 105-125). Expression of $\triangle \mathrm{CR}$ PrP in transgenic $(\mathrm{Tg})$ mice causes a neonatal lethal phenotype characterized by spontaneous degeneration of cerebellar granule neurons (CGNs), as well as white matter pathology in the brain and spinal cord ( Li et al., 2007b). Importantly, this $\Delta \mathrm{CR}$ induced phenotype is suppressed by coexpression of wild-type (WT) PrP, suggesting that mutant and WT forms can somehow interact at a functional level.

An important insight into the toxicity of $\Delta C R \operatorname{PrP}$ is provided by our observation that $\mathrm{PrP}$ molecules carrying deletions or disease-associated point mutations in the central region induce large, spontaneous ionic currents when expressed in transfected cell lines (Solomon et al., 2010b). We also discovered that cells expressing these mutants are hypersensitive to the toxic effects of several cationic drugs, a phenomenon that is likely related to enhanced current activity (Massignan et al., 2010). WT PrP suppresses $\Delta$ CR-induced currents and drug hypersensitivity, 
paralleling the ability of the WT protein to reverse the neurodegenerative phenotype of $\operatorname{Tg}(\Delta \mathrm{CR})$ mice. Our interpretation of these results is that $\Delta \mathrm{CR} \operatorname{PrP}$ molecules form ion channels or pores in the plasma membrane, or else activate endogenous ion channels, and that these channels are silenced by coexpression of WT PrP (Solomon et al., 2012).

These results raise the possibility that abnormal ion channel activity is a major cause of neurodegeneration in $\operatorname{Tg}(\Delta \mathrm{CR}$ mice $)$. Excessive excitation of CNS neurons, attributable to activating mutations in ion channel proteins or to increased stimulation by the neurotransmitter glutamate, are well-known causes of neuronal death in animal models and human diseases (Michaelis, 1998). In this study, we report that $\Delta \mathrm{CR}$ PrP induces spontaneous current activity in several kinds of neuronal preparations and also sensitizes neurons to glutamate-mediated excitotoxic death. These effects are suppressed by coexpression of WT PrP or by cotreatment with an NMDA antagonist. Our results provide a likely explanation for the toxicity of $\Delta \mathrm{CR} \operatorname{PrP}$ in vivo and raise the possibility that a similar excitotoxic mechanism may occur in infectious prion diseases and possibly other neurodegenerative conditions resulting from binding of $\beta$-rich protein oligomers to $\operatorname{PrP}^{\mathrm{C}}$.

\section{Materials and Methods}

Mice. All experiments were performed in accordance with the recommendations in the Guide for the Care and Use of Laboratory Animals of the National Institutes of Health. For experiments involving CGNs and cerebellar slice cultures, $\Delta \mathrm{CR}-\mathrm{A}^{+/-} / \mathrm{Prn}-\mathrm{p}^{+/-}$mice (Li et al., 2007b) were used. $\Delta$ CR-A ${ }^{+/-} /$Prn- $p^{+/-} /$Tga20 ${ }^{+/-}$(Fischer et al., 1996) and Prn$p^{+/-}$(Büeler et al., 1992) littermates served as controls. C57BL/6 (C57) mice were obtained from The Jackson Laboratory. Mice were genotyped by PCR analysis of tail DNA, prepared using the Puregene DNA Isolation Kit (Gentra Systems). To obtain neural stem cells (NSCs) of different genotypes, $\Delta$ CR-A ${ }^{+/-} /$Tga $20^{+/-} / P r n-p^{+/-}$mice were mated to Prn$p^{-/-}$mice on the C57BL/6 background, as described previously (Massignan et al., 2010; Biasini et al., 2012b). E13.5 mouse embryos were genotyped by PCR analysis of limb DNA.

CGNs. CGNs were cultured from postnatal day 5 (P5) mice as described previously (Li et al., 2007b). Cerebella were removed from Prn$p^{-1-}$ mice or $\operatorname{Tg}(\Delta \mathrm{CR})-\mathrm{A}$ mice, and neurons were isolated by mechanical disruption and trypsinization. Neurons $\left(350,000\right.$ cells $\left./ \mathrm{cm}^{2}\right)$ were plated on poly-L-lysine-coated coverslips in Basal Media Eagle with Earle's salts supplemented with $10 \%$ dialyzed fetal calf serum, 2 mm glutamine, 25 $\mathrm{mm} \mathrm{KCl}$, and $0.02 \mathrm{mg} / \mathrm{ml}$ gentamycin. Aphidicholin $(3.3 \mu \mathrm{g} / \mathrm{ml})$ was added to cultures $1 \mathrm{~d}$ after plating. Two days after plating, $\mathrm{Pr} \mathrm{P}^{-/-} \mathrm{CGNs}$ were transduced with recombinant lentiviruses.

Lentiviruses were constructed according to published procedures (White et al., 2008). cDNAs encoding either enhanced GFP alone or WT or $\Delta$ CR PrP followed by an internal ribosomal entry site and enhanced GFP were cloned into the transfer vector pRRLsinCMV. HEK293T packaging cells were cotransfected with the resulting transfer plasmid, along with the plasmids pMD-Lg, pCMV-G, and RSV-REV. Virus was collected from the medium and concentrated.

Viral transductions were performed by incubating cells with purified virus at a multiplicity of infection of 0.1-2.0. Two days after lentiviral transduction, CGNs were collected for Western blotting or stained by immunofluorescence. Western blots were probed with anti-PrP antibody 6D11, followed by goat anti-mouse IgG (Pierce), and developed with ECL (GE Healthcare). Surface immunofluorescence staining was performed by incubating cells on ice with 6D11, after which they were fixed in 4\% paraformaldehyde in PBS and labeled with Alexa Fluor-488 goat anti-mouse IgG (Invitrogen). Cells were viewed with a $40 \times$ objective on a Nikon TE-2000E inverted fluorescence microscope, and images were captured with MetaMorph software (Molecular Devices).

NSCs. NSCs were obtained and cultured following a procedure described previously, with minor modifications (Massignan et al., 2010; Biasini et al., 2012b). Brains dissected from E13.5 mouse embryos were triturated in $5 \mathrm{ml}$ of NeuroCult NSC basal medium containing NeuroCult NSC proliferation supplement (StemCell Technologies) along with $20 \mathrm{ng} / \mathrm{ml}$ EGF. Once formed, neurospheres were differentiated by pipetting a $0.1-1 \mathrm{ml}$ suspension (containing $\sim 30-40$ mature neurospheres) into each well of an eight-well chamber slide (Ibidi) containing NeuroCult NSC basal medium with NeuroCult NSC differentiation supplement (StemCell Technologies) along with $10 \mu \mathrm{g} / \mathrm{ml}$ retinoic acid. NSCs differentiated for $10 \mathrm{~d}$ were treated with $500 \mu \mathrm{M}$ glutamate for $24 \mathrm{~h}$ and stained with propidium iodide (PI) (Sigma-Aldrich) to estimate the number of dead cells and with $4^{\prime}$,6-diamidino-2-phenylindole (DAPI) to detect cell nuclei.

$\mathrm{Ca}^{2+}$ measurement in differentiated NSCs. Cells were washed with Krebs-Ringer-HEPES (KRH) buffer (in mM: $128 \mathrm{NaCl}, 5 \mathrm{KCl}, 1.2$ $\mathrm{MgSO}_{4} 2 \mathrm{CaCl}^{2}, 10$ glucose, and 25 HEPES, pH 7.4) and incubated with $10 \mu \mathrm{M}$ fura- $2 \mathrm{AM}$ in $\mathrm{KRH}$ buffer plus $1 \% \mathrm{BSA}$, for $30 \mathrm{~min}$ at $37^{\circ} \mathrm{C}$. After washing once with KRH buffer, chamber slides were transferred to the recording chamber of an Olympus IX81 inverted microscope equipped with a $\mathrm{Ca}^{2+}$ imaging unit (Cell R; Olympus). Fluorescence was measured at $37^{\circ} \mathrm{C}$ in $5 \% \mathrm{CO}_{2} / 95 \%$ air by recording $669 \mathrm{~ms}$ frames for 100 cycles, each cycle alternating excitation at 340 and $380 \mathrm{~nm}$ and monitoring emission at $510 \mathrm{~nm} . \mathrm{Ca}^{2+}$ response was measured after exposure to 0.5 mM glutamate beginning at cycle 20 . The fluorescence ratio $F_{340} / F_{380}$ was measured for each cycle, and kinetic analysis of $F_{340} / F_{380}$ was done by CellR software (Olympus). Data are reported as $\Delta F_{340} / F_{380}$, the difference between $F_{340} / F_{380}$ before and after the stimulus, which is proportional to the glutamate-induced $\mathrm{Ca}^{2+}$ influx.

Neuronal and non-neuronal cells were distinguished based on expression of microtubule-associated protein 2 (MAP2). After acquiring data for $\mathrm{Ca}^{2+}$ influx, the position of the microscope stage was recorded to allow exact realignment of each chamber slide. Cells were immediately fixed with $4 \%$ paraformaldehyde in $200 \mathrm{~mm} \mathrm{HEPES} / \mathrm{NaOH}$, pH 7.4, for $30 \mathrm{~min}$ at room temperature, washed in PBS, and incubated in blocking solution ( $1 \%$ bovine serum albumin, $50 \mathrm{mM} \mathrm{NH}_{4} \mathrm{Cl}$, and $0.1 \%$ saponin in PBS, pH 7.4) containing $10 \%$ normal goat serum for $30 \mathrm{~min}$ at room temperature. Cells were then incubated with primary antibody antiMAP2 (Sigma) diluted 1:1000 in blocking solution overnight at $4^{\circ} \mathrm{C}$. After washing in PBS, cells were incubated for $1 \mathrm{~h}$ at room temperature with Alexa Fluor-594-conjugated secondary antibody (1:500) and then reacted with $300 \mathrm{~nm}$ DAPI (Invitrogen) in PBS for $10 \mathrm{~min}$ at room temperature to stain nuclei. Finally, the chamber slide was realigned under the microscope, and $\mathrm{Ca}^{2+}$ measurements were assigned to MAP2positive or -negative cells.

Organotypic slice cultures of mouse cerebellum. After decapitation, brains were removed quickly, and the cerebellum was transferred to a container with liquid agarose (low-melting point, prepared freshly each day at $2 \%$ in HBSS; both reagents obtained from Invitrogen). After the agarose was cooled on ice, agarose blocks were glued onto a vibratome disc, which was then placed in ice-cold HBSS in the buffer reservoir of a Vibratome 1000Plus Sectioning system. Several $300 \mu \mathrm{m}$ sagittal slices were cut at medium speed and amplitude. Slices were collected in a Petri dish containing ice-cold HBSS with $0.5 \%$ glucose and released from the agarose under a stereomicroscope using fine forceps. All subsequent steps were performed under sterile conditions in a cell culture hood.

Each slice was placed in a Millicell Cell Culture insert (Millipore) in a 24 -well cell culture plate. Culture wells contained $200 \mu \mathrm{l}$ of slice culture medium consisting of $50 \%$ minimum essential medium (with Earle's salts, 25 mM HEPES, without L-glutamine; Invitrogen), 22.5\% HBSS, $25 \%$ horse serum (heat-inactivated; Invitrogen), $50 \mathrm{U} / \mathrm{ml}$ penicillin $/ 50$ $\mu \mathrm{g} / \mathrm{ml}$ streptomycin (Invitrogen), $0.5 \%$ glucose, and $2 \mathrm{~mm}$ L-glutamine (Invitrogen). Slice cultures were kept under standard cell culture conditions $\left(37^{\circ} \mathrm{C}, 5 \% \mathrm{CO}_{2}\right)$ in a humidified atmosphere with the medium being changed every other day.

Toxicity assays were performed by adding to the culture media for $24 \mathrm{~h}$ : L-glutamic acid (500 $\mu \mathrm{M})$, kainic acid, NMDA, and AMPA (all at 10 $\mu \mathrm{M}$; purchased from Sigma-Aldrich); or Zeocin (500 $\mu \mathrm{g} / \mathrm{ml}$; Invitrogen). To assess cell death, cerebellar slices were kept in culture for varying time spans, after which they were incubated with $2 \mu \mathrm{M}$ PI in culture medium for $30 \mathrm{~min}$ in a cell culture incubator. Red fluorescence was imaged on a Nikon TE2000E2 microscope with a $20 \times$ long-working-range objective. 
In some cases, nuclear labeling was performed by staining with Hoechst $34580(2 \mu \mathrm{g} / \mathrm{ml}$; Invitrogen). Several images of the cerebellar granule layer of each slice were obtained using the auto-expose function of the camera. Positive nuclei were counted with the same settings for brightness and diameter for each image using MetaMorph software (Molecular Devices).

For characterization and documentation of the quality of each slice culture, some of the slices were fixed in $4 \%$ buffered Formalin for $1 \mathrm{~h}$ at $4^{\circ} \mathrm{C}$, then washed with PBS several times, and subjected to paraffin embedding and hematoxylin and eosin $(\mathrm{H} \& \mathrm{E})$ staining or immunofluorescence staining. For paraffin embedding, slices were carefully removed from the membranes, placed between two biopsy foam pads in an embedding cassette, and processed according to standard histology procedures. Four-micrometer sections were stained with $\mathrm{H} \& \mathrm{E}$ and assessed using a conventional light microscope.

All incubation steps for immunofluorescence staining were performed with the slices still sitting on the membranes. First, slices were immersed in a blocking solution containing $0.3 \%$ Triton X-100 and $10 \%$ fetal calf serum (heat-inactivated; Invitrogen) for $24 \mathrm{~h}$ at $4^{\circ} \mathrm{C}$. On the following day, an antibody against neuronal nuclei (mouse monoclonal antiNeuN; clone A60; Millipore Bioscience Research Reagents) was added at a 1:1000 dilution in blocking solution and left for $48 \mathrm{~h}$ at $4^{\circ} \mathrm{C}$. After three washes in PBS/0.3\% Triton X-100, an Alexa Fluor-488 rabbit anti-mouse antibody (Invitrogen) was added at a 1:200 dilution in PBS/0.3\% Triton $\mathrm{X}-100$ for $4 \mathrm{~h}$ at room temperature in the dark. Finally, slices were washed again three times in PBS and imaged using a Nikon TE2000E2 inverted fluorescence microscope equipped with a CCD camera.

All reagents for electron microscopic analysis of organotypic cerebellar slices were purchased from Ted Pella. Slices were washed twice with cacodylic acid buffer and fixed for $24 \mathrm{~h}$ at $4^{\circ} \mathrm{C}$ in $4 \%$ glutaraldehyde in cacodylic acid buffer. After another two washes in cacodylic acid buffer, the specimens were dehydrated through an ascending alcohol series. An epoxy resin consisting of dodecenyl succinic anhydride and Araldite 502 in a 1:1 relationship was added to the membrane inserts, and the inserts were left on a shaker at room temperature for $2 \mathrm{~d}$. Membrane patches with slices were punched out and transferred to glass vials containing epoxy resin with $2 \%$ benzyldimethylamin, which were left on a rotating shaker for $1 \mathrm{~h}$. Membranes were then placed in electron microscopy molds with resin and left to solidify in a vacuum cabinet. Ultrathin sections were prepared from each block and stained with lead citrate according to standard electron microscopy protocols.

Electrophysiology. Whole-cell patch-clamp recordings were made from CGNs after $4 \mathrm{~d}$ in culture or $4 \mathrm{~d}$ after lentiviral transduction. Pipettes were pulled from borosilicate glass, coated with Sylgard, and polished to an open resistance of 1-10 M $\Omega$. Experiments were conducted at room temperature with the following solutions in the patch pipette and extracellular medium (in $\mathrm{mm}$ ): internal, $140 \mathrm{Cs}$-glucuronate, $5 \mathrm{CsCl}, 4$ MgATP, $1 \mathrm{Na}_{2}$ GTP, 10 EGTA, and 10 HEPES, pH 7.4 with CsOH; external, $150 \mathrm{NaCl}, 4 \mathrm{KCl}, 2 \mathrm{CaCl}_{2}, 2 \mathrm{MgCl}_{2}, 10$ glucose, and 10 HEPES, pH 7.4 with $\mathrm{NaOH}$. Current signals were collected from an Axopatch 200B amplifier and digitized with a Digidata 1330 interface (Molecular Devices) or with an EPC-10 amplifier controlled by PatchMaster acquisition software (HEKA) and were saved to disc for analysis with pClamp 9 software. Current activity was plotted as the proportion of total recording time that a cell exhibited inward current $\geq 450 \mathrm{pA}$.

To prepare cerebellar slices for acute recordings, $\operatorname{Prn}_{-} \mathrm{p}^{+/-} \Delta \mathrm{CR}-\mathrm{A}^{-1-}$ and Prn- $\mathrm{p}^{+/-} \Delta \mathrm{CR}-\mathrm{A}^{+/-}$mice at P10 were killed by decapitation, and their brains were immediately submerged in oxygenated $\left(95 \% \mathrm{O}_{2}, 5 \%\right.$ $\mathrm{CO}_{2}$ ) ice-cold Ringer's solution (in mM: $25 \mathrm{NaHCO}_{3}, 124 \mathrm{NaCl}, 1 \mathrm{KCl}, 2$ $\mathrm{KH}_{2} \mathrm{PO}_{4}, 10$ glucose, $2.5 \mathrm{CaCl}_{2}$, and $1.3 \mathrm{MgCl}_{2}, \mathrm{pH}$ 7.4). Cerebella were affixed to an agar slab with cyanoacrylate glue and placed in a tissue holder for cutting. Four to six slices ( $300 \mu \mathrm{m}$ thick) were cut into ice-cold Ringer's solution with a vibrating microtome and then equilibrated for at least $1 \mathrm{~h}$ at room temperature in oxygenated Ringer's solution. Individual slices were positioned in a submersion-type recording chamber (Harvard Apparatus) on the stage of a Nikon E600 infrared-differential interference contrast microscope (Micro Video Instruments) and were continuously perfused with room temperature with oxygenated Ringer's solution (2-2.5 $\mathrm{ml} / \mathrm{min})$. Whole-cell patch-clamp recordings were ob- tained from CGNs at a potential of $-80 \mathrm{mV}$. Patch electrode pipettes were pulled from capillary tubes on a Flaming/Brown horizontal pipette puller (model P87; Sutter Instruments) to a resistance of 3-6 M $\Omega$ and were filled with potassium glucuronate (KGlu) internal solution $(122 \mathrm{~mm}$ KGlu, $2 \mathrm{~mm} \mathrm{MgCl}_{2}$, 5 mм EGTA, 10 mм NaHEPES, 2 mм MgATP, 0.3 mM NaGTP, and $1 \%$ biocytin, pH 7.4). PatchMaster software was used for data acquisition with EPC-9 and EPC-10 amplifiers, and data were saved to disc for analysis with pClamp 9 software.

\section{Results}

$\Delta \mathrm{CR}$ PrP induces spontaneous ionic currents in CGNs

We recently reported that $\Delta \mathrm{CR} \operatorname{PrP}$ induces spontaneous ionic currents in a variety of transformed cell lines (Solomon et al., 2010b, 2011). Here, we sought to determine whether $\Delta$ CR PrP also exerts such an activity in neurons. First, CGNs were cultured from P5 PrP-null mice and transduced with lentiviruses encoding WT or $\Delta$ CR PrP. Each construct included an internal ribosome entry site and a GFP gene, allowing us to monitor protein expression in individual cells by visualizing the intrinsic green fluorescence of the GFP. Cells transduced with "GFP-only" lentiviruses were used as controls. Surface immunofluorescence staining showed the lack of PrP signal in the GFP-only control cells and both PrP and GFP signals in CGNs transduced with WT or $\Delta \mathrm{CR}$ PrP-encoding lentiviruses (Fig. $1 A$ ). These analyses also confirmed that PrP molecules, either WT or $\Delta \mathrm{CR}$, were correctly expressed at the neuronal surface. Whole-cell patch-clamp recordings were then collected $48 \mathrm{~h}$ after lentiviral transduction (4 $\mathrm{d}$ after culturing) from GFP-positive cells, at a holding potential of $-80 \mathrm{mV}$ (Fig. $1 \mathrm{~B}, \mathrm{C}$ ). $\Delta \mathrm{CR}$ PrP-expressing CGNs, but not WT or GFP-only controls, exhibited large, spontaneous inward currents similar to those observed previously in transformed cell lines (Solomon et al., 2010b).

To determine whether neurons derived from $\operatorname{Tg}(\Delta \mathrm{CR})$ mice also exhibited spontaneous currents, CGNs were cultured from P5 mice expressing $\Delta \mathrm{CR} \operatorname{PrP}$ on the $P r P^{+/-}$background $\left(\Delta \mathrm{CR}^{+/-}\right.$/ Prn- $p^{+/-}$, referred to as $\left.\Delta \mathrm{CR} / \mathrm{PrP}\right)$. The presence of endogenous $\operatorname{PrP}(0.5 \times)$ was required for recovery of sufficient numbers of postnatal animals, because expression of $\Delta \mathrm{CR}$ PrP on a PrP-null background induces neonatal lethality, with mice often dying within the first week after birth, whereas $\operatorname{Tg}\left(\Delta \mathrm{CR}^{+/-} / \mathrm{Prn}_{-} \mathrm{p}^{+/-}\right)$ mice survive $\sim 3$ weeks (Li et al., 2007b). CGNs from $\operatorname{Tg}(\Delta \mathrm{CR})$ mice overexpressing WT PrP from a second transgene $\left(\Delta \mathrm{CR}^{+/-}\right.$/ Tga20 $0^{+/-} /$Prn $-p^{+/-}$, referred to as $\left.\Delta \mathrm{CR} / \mathrm{Tga}\right)$ or non-Tg C57 mice expressing one copy of endogenous $\operatorname{PrP}\left(\operatorname{Pr} P^{+/-}\right)$were used as controls. Four days after culturing, whole-cell patch-clamp recordings were collected at a potential of $-80 \mathrm{mV}$ (Fig. 1D,E). $\Delta \mathrm{CR}$ cells exhibited spontaneous inward currents, which were absent in $\Delta \mathrm{CR} /$ Tga and $\operatorname{Pr} P^{+/-}$control cells. These currents were of similar magnitude to those observed in lentivirus-transduced CGNs. However, we noted that the frequency and duration of the currents were less, most likely because of the partial channel silencing effect of endogenous PrP expression.

Together, these results demonstrate that $\Delta \mathrm{CR}$ PrP-dependent channel activity is not restricted to transformed cell lines but can also be detected in primary neurons, either virally transduced or taken from $\operatorname{Tg}(\Delta \mathrm{CR})$ mice.

\section{Expression of $\Delta C R$ PrP causes spontaneous ionic currents and increased neuronal fragility in acute cerebellar slices}

To extend the observations made in cultured CGNs, we sought to determine whether $\Delta$ CR PrP-dependent ionic currents can be detected in neurons in cerebellar slices. Acute slice cultures were made from $\mathrm{P} 10 \Delta \mathrm{CR} / \mathrm{PrP}$ and $\Delta \mathrm{CR} / \mathrm{Tga}$ mice. Whole-cell patch- 
A
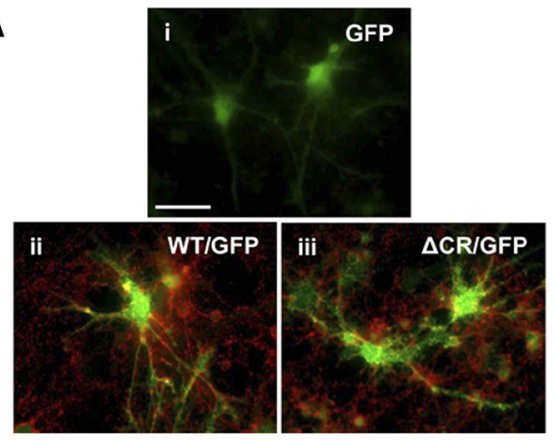

B

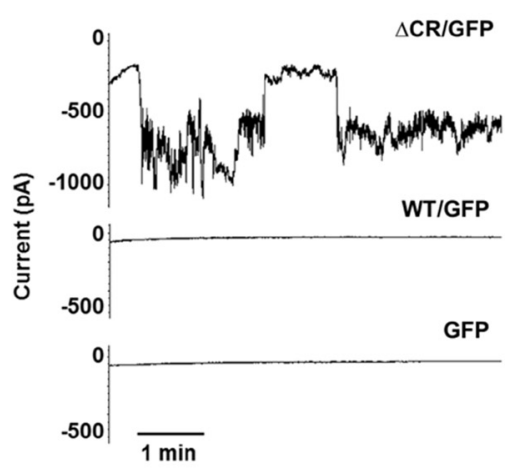

C

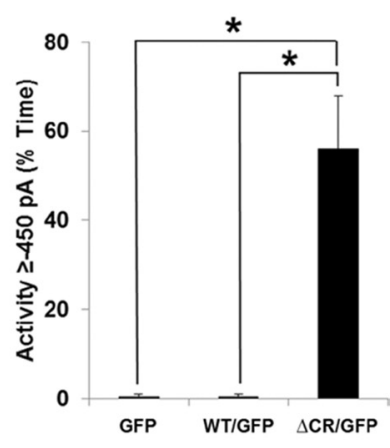

D

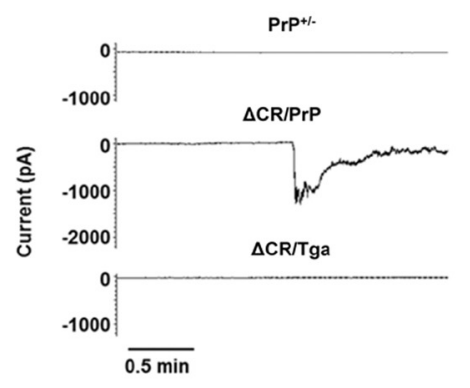

E

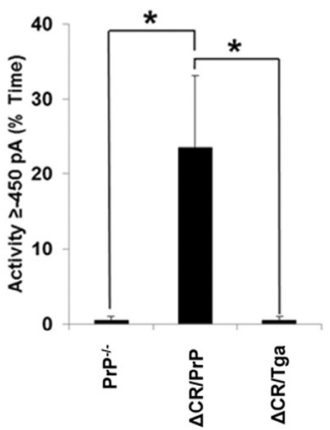

$\mathbf{F}$
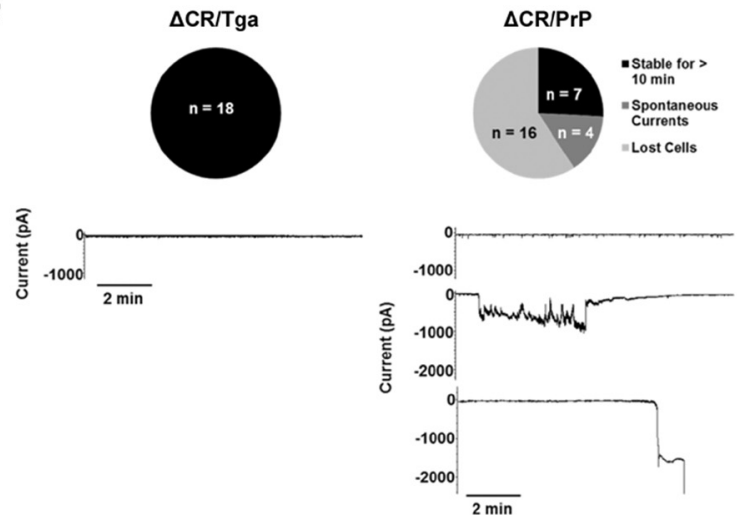

Figure 1. $\Delta$ CRPrP induces spontaneous ionic currents in CGNs. A-C, CGNs isolated from P5 PrP ${ }^{-1-}$ mice were transduced with recombinant lentiviruses encoding GFP alone (i) or GFP plus either WT (ii) or $\Delta$ CR PrP (iii). A, Surface immunofluorescence staining shows PrP expression (red) in GFP (green) containing neurons (ii, iii). Coincidence of PrP fluorescence (on the cell membrane) and EGFP fluorescence (in the cytoplasm) is most evident in neuronal processes, in which PrP is preferentially expressed. Scale bar, $50 \mu \mathrm{m}$. $\boldsymbol{B}$, Whole-cell patch-clamp recordings were made at a holding potential of $-80 \mathrm{mV}$ from GFP-positive cells $48 \mathrm{~h}$ after transduction. C, Quantitation of the currents recorded in $\boldsymbol{B}$, plotted as the percentage of total time the cells exhibited inward current at 450 $\mathrm{pA}$ (mean $\pm \mathrm{SEM}, n=5$ cells). ${ }^{*} p<0.05$, statistically significant differences in spontaneous channel activity, one-tailed Student's $t$ test. $\boldsymbol{D}$, CGNs were cultured from Tg mice with the following genotypes: $\mathrm{PrP}^{+/-} ; \Delta \mathrm{CR}^{+/-} / \mathrm{PrP}^{+/-}(\Delta \mathrm{CR} / \mathrm{PrP}) ;$ or $\Delta \mathrm{CR}^{+/-} / \mathrm{Tga} 20^{+/-} / \mathrm{PrP}^{+/-}(\Delta \mathrm{CR} / \mathrm{Tga})$. Whole-cell patch-clamp recordings were made at a potential of $-80 \mathrm{mV}$. E, Quantitation of the currents recorded in $\boldsymbol{D}$, plotted as the percentage of total time the cells exhibited inward current of $450 \mathrm{pA}$ (mean $\pm S E M, n=5$ cells). ${ }^{*} p<0.05$, statistically significant differences in spontaneous channel activity, one-tailed Student's t test. $F$, Expression of $\Delta C R$ PrP induces spontaneous currents and increases fragility of CGNs in acute cerebellar slices. Cerebellar slices dissected from P10 mice of the indicated genotypes were allowed to equilibrate in external recording buffer for $1 \mathrm{~h}$ before whole-cell patch-clamp recordings at $-80 \mathrm{mV}$. Unlike CGNs from $\Delta$ CR/Tga mice, which remain stable for $>10$ min of recording without current activity, the majority of CGNs in $\Delta C R / P r P$ slices exhibited spontaneous inward currents that returned to baseline or were unable to be observed for $10 \mathrm{~min}$ because of cell death or instability of the patch. The pie charts indicate the number and proportion cells in each category.

clamp recordings were collected at $-80 \mathrm{mV}$ from neurons in the granule cell layer (Fig. $1 F$ ). As expected, no currents were detected in $\Delta \mathrm{CR} / \mathrm{Tga}$ cells for the entire duration of the recordings $(>10 \mathrm{~min})$. In contrast, several $\Delta \mathrm{CR} / \mathrm{PrP}$ neurons exhibited large, spontaneous inward currents similar to those observed in cultured CGNs. However, in a few cases, no currents were detected. As discussed for CGNs, this assortment of phenotypes could possibly be explained by the presence of endogenous PrP in $\Delta \mathrm{CR} / \mathrm{PrP}$ slices. We found that the majority of $\Delta \mathrm{CR}$ cells were lost shortly after initial patching, frequently after detection of an initial inward current that did not return to baseline. This problem, which was never encountered with $\Delta \mathrm{CR} / \mathrm{Tga}$ cells, occurred in slices from several $\Delta \mathrm{CR} / \operatorname{PrP}$ mice derived from multiple litters. The phenomenon, which may reflect an intrinsic fragility of the neuronal membrane, suggests that $\Delta \mathrm{CR}$-induced channel activity is deleterious for primary neurons.

$\Delta C R$ PrP sensitizes neurons in differentiated cultures of NSCs to glutamate-evoked $\mathrm{Ca}^{2+}$ influx and cell death In vivo, CGNs receive glutamate-mediated excitatory input from mossy fibers originating in the deep cerebellar nuclei (Martin, 1996). Therefore, we decided to investigate whether the channel activity generated by $\Delta \mathrm{CR} \operatorname{PrP}$ can alter neuronal sensitivity to glutamate. For these experiments, we used differentiated NSCs. We showed previously that these cells are susceptible to the toxic effect of $\Delta$ CR PrP, which makes them hypersensitive to the cationic antibiotics Zeocin and G418 (Biasini et al., 2012b). NSCs provide several advantages over CGNs. Because NSCs are derived from mice at E13.5, they can be obtained from $\operatorname{Tg}(\Delta \mathrm{CR})$ mice on a Prn- $p^{-/-}$background, eliminating the confounding effects attributable to expression of endogenous PrP. Moreover, during differentiation, NSCs give rise to mixed cultures of mature astrocytes, oligodendrocytes, and neurons, allowing us to determine the effect of glutamate on both neuronal and non-neuronal cells within the same culture.

To test the hypothesis that $\Delta \mathrm{CR} \operatorname{PrP}$ alters glutamatemediated excitability, we preloaded NSCs with the ratiometric $\mathrm{Ca}^{2+}$ indicator fura-2 AM to monitor influx of $\mathrm{Ca}^{2+}$ through glutamate receptor channels, predominantly of the NMDA subtype. We derived NSCs from several mouse lines, including non-Tg C57, Prn- $p^{-/-}[$knock-out $(\mathrm{KO})]$, Tga $20^{+/+} /$Prn- $p^{-/-}$ (Tga), $\operatorname{Tg}\left(\Delta \mathrm{CR} / \mathrm{Prn}_{-} \mathrm{p}^{-/-}\right)(\Delta \mathrm{CR})$, and $\mathrm{Tg}(\Delta \mathrm{CR} / \mathrm{Tga} 20 /$ Prn$\left.p^{-1-}\right)(\Delta \mathrm{CR} / \mathrm{Tga})$ mice. $\mathrm{Ca}^{2+}$ influx before and after stimulation with $0.5 \mathrm{~mm}$ glutamate was measured by ratiometric quantifica- 
tion of fluorescence corresponding to free or $\mathrm{Ca}^{2+}$-bound fura-2 $\left(F_{340} / F_{380}\right)$, on both neuronal (MAP2-positive) and glial (MAP2-negative) cells (for details, see Material and Methods). These analyses revealed that a significantly higher concentration of $\mathrm{Ca}^{2+}$ accumulates in the cytoplasm of $\Delta \mathrm{CR}$ neurons in response to glutamate compared with $\mathrm{C} 57, \mathrm{KO}$, or Tga neurons (Fig. 2A,B). We also found that that intracellular $\mathrm{Ca}^{2+}$ concentrations returned to baseline with slower kinetics in $\triangle \mathrm{CR}$ neurons compared with control cells (Fig. 2A). Importantly, the kinetics of glutamate-evoked $\mathrm{Ca}^{2+}$ influx and recovery were restored to normal when WT PrP was coexpressed with the $\Delta \mathrm{CR}$ mutant ( $\Delta \mathrm{CR} / \mathrm{Tga}$ NSCs). Moreover, no difference was detected between $\Delta \mathrm{CR}$ and controls when glutamatedependent $\mathrm{Ca}^{2+}$ influx was recorded in glial cells (Fig. 2C,D). These results indicate that expression of $\Delta C R$ PrP causes an enhanced $\mathrm{Ca}^{2+}$ response to glutamate stimulation selectively in neuronal cells, an effect that is rescued by WT PrP.

Excessive influx of $\mathrm{Ca}^{2+}$ in response to glutamate stimulation can cause excitotoxic neuronal death. To test whether $\Delta \mathrm{CR}$ cells are hypersensitive to glutamate-induced excitotoxicity, we chronically exposed C57, KO, Tga, $\Delta \mathrm{CR}$, and $\Delta \mathrm{CR} / \mathrm{Tga}$ differentiated NSCs to glutamate and scored cell death by PI staining (Fig. $3 A$ ). In all the experimental groups, we found that the vast majority of PI-positive cells ( $>90 \%)$ were also positive for MAP2 staining, suggesting that neuronal cells are more susceptible to excitotoxicity than glial cells (data not shown). However, we detected a significantly higher (more than twofold increase) number of PI-positive cells in cultures of $\Delta \mathrm{CR}$ NSCs compared with cultures of control cells (Fig. 3B). Glutamate sensitivity in $\triangle \mathrm{CR}$ cells was restored to normal levels by coexpression of WT PrP (Fig. 3B, green bar) or by cotreatment with MK-801, a noncompetitive NMDA receptor antagonist (Fig. 3C, red stripes bar). These results, which are consistent with the observed increase in $\mathrm{Ca}^{2+}$ influx after glutamate stimulation, provide direct evidence that $\Delta \mathrm{CR} \operatorname{PrP}$ hypersensitizes neurons to glutamate-induced excitotoxicity and that this effect requires activation of NMDA receptors.

We reported previously that granule cell death in $\operatorname{Tg}(\Delta \mathrm{CR})$ mice occurs by a non-apoptotic mechanism that is independent of caspase or Bax activation (Christensen et al., 2010). To test the involvement of caspase- 3 in glutamate-induced cell death of differentiated $\Delta$ CR NSCs, we chronically exposed C57, KO, Tga, and $\Delta \mathrm{CR}$ differentiated NSCs to glutamate and scored cell death by PI staining or staining for activated caspase-3 (Fig. 4). As expected, a much greater number of $\Delta \mathrm{CR}$ cells were positive for PI staining compared with cells from control genotypes (Fig. 4, red bar). In contrast, we observed no difference in the number of cells positive for activated caspase-3 (Fig. 4, striped bars). These results are consistent with previous studies indicating that NMDA-induced excitotoxicity is not associated with activation of classical apoptotic markers (Forloni et al., 1997).
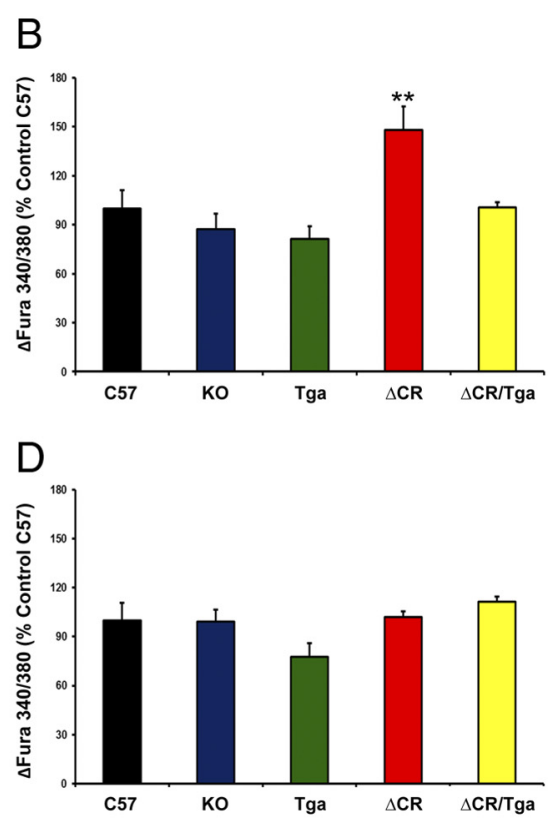

Figure 2. $\quad \Delta C R$ PrP causes abnormal, glutamate-induced $\mathrm{Ca}^{2+}$ influx in NSC-derived neurons. NSCs dissected from mouse emes cultured and propagated as neurospheres, differentiated for $7 \mathrm{~d}$, and then incubated with the $\mathrm{Ca}^{2+}$ atternating excitation at 340 and $380 \mathrm{~nm}$ and monitoring emission at $510 \mathrm{~nm}$. Raw data were collected as the ratio $F_{340} / F_{380}$, which D) on the basis of the expression of the MAP2, which was detected by immunostaining after acquiring $\mathrm{Ca}^{2+}$ influx recordings. graphs show quantitation of the $\mathrm{Ca}^{2+}$ burst in the different cells, calculated as the difference between $F_{340} / F_{380}$ before and after reported as percentage of the $C 57$ control. ${ }^{* *} p<0.01$, one-tailed Student's $t$ test.

\section{Characterization of organotypic cerebellar slice cultures derived from $\operatorname{Tg}(\Delta \mathrm{CR})$ mice}

To confirm the data obtained with NSCs, we used organotypic cerebellar slice (OCS) cultures. For these experiments, we cut sagittal OCSs from $\operatorname{Pr} P^{+/-}, \Delta \mathrm{CR} / \operatorname{Pr} P^{+/-}$, and $\Delta \mathrm{CR} /$ Tga mice between P10 and P12. Slices were then kept in culture for $\sim 15 \mathrm{~d}$. Slice integrity and morphology were confirmed by H\&E staining after fixation and embedding in paraffin (Fig. $5 \mathrm{~A}$ ), and by immunofluorescence staining for the neuronal marker NeuN (Fig. $5 B, C)$. Detection of cell nuclei by Hoechst staining revealed that the total number of granule neurons in each slice at the time it was placed in culture was not detectably different in OCSs from different genotypes (data not shown).

As described previously, despite the potent neurotoxicity of $\Delta \mathrm{CR} \operatorname{PrP}$ in vivo, only a small increase in spontaneous cell death can be detected in transformed cell lines transfected to express $\Delta$ CR PrP (Christensen and Harris, 2009; Massignan et al., 2010). However, the number of dying $\Delta$ CR cells dramatically increases after treatment with the cationic antibiotics Zeocin, G418, or hygromycin. To confirm these observations in OCSs, we quantitated the proportion of PI-positive cells in slices from $\mathrm{PrP}^{+/-}$, $\Delta \mathrm{CR} / \operatorname{PrP}^{+/-}$, or $\Delta \mathrm{CR} / \mathrm{Tga}$ mice, before and after treatment with Zeocin. In the absence of Zeocin, we detected a small but significantly higher percentage of PI-positive cells in OCSs derived from $\Delta \mathrm{CR} / \mathrm{Pr} \mathrm{P}^{+/-}$mice compared with $\mathrm{PrP}^{+/-}$controls (2.6 vs $5.2 \%, p<0.01$ ) (Fig. $6 A, B$ ). As expected, $\Delta \mathrm{CR} / \operatorname{Pr} P^{+/-}$OCSs showed hypersensitivity to Zeocin, because the proportion of PI-positive cells was increased by $>10$-fold after treatment (Fig. 6C,D) compared with twofold for $\mathrm{PrP}^{+/-}$control cells. Importantly, both the spontaneous cell death and the hypersensitivity to Zeocin were fully suppressed by overexpression of WT PrP from 
A

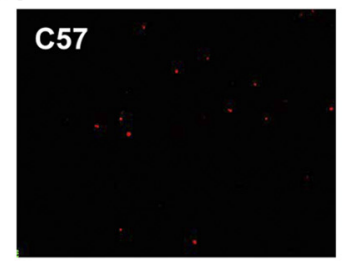

B
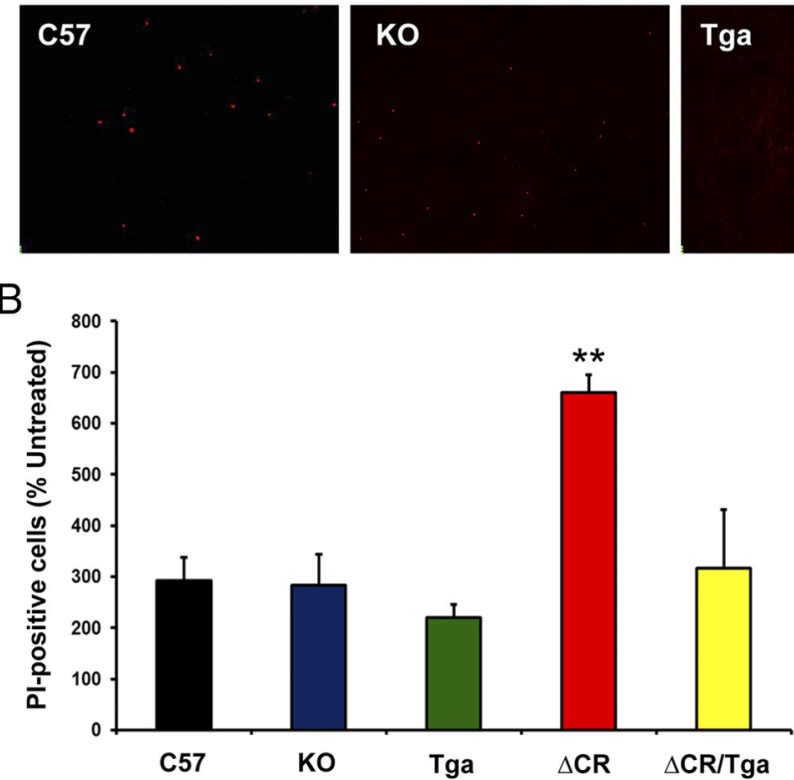
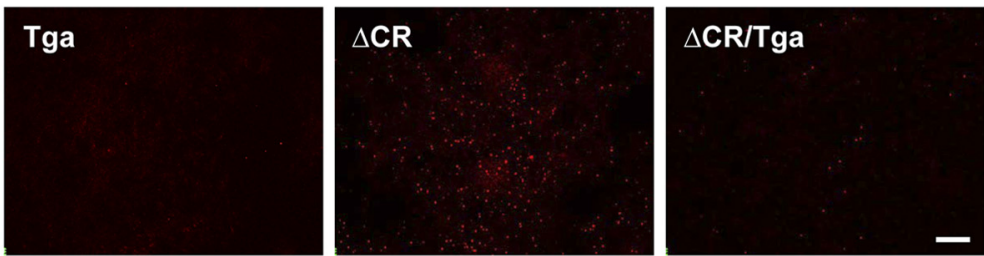

C

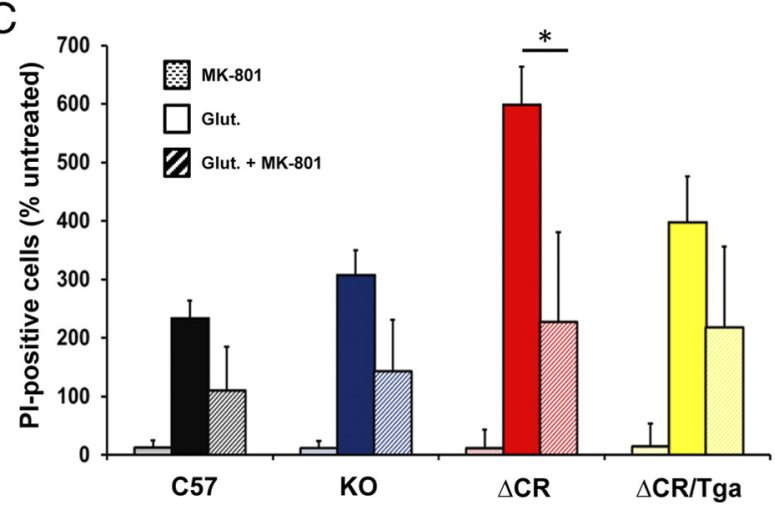

Figure 3. Differentiated NSCs expressing $\Delta$ CR PrP are hypersensitive to glutamate-induced excitotoxicity. $\boldsymbol{A}$, Differentiated NSCs of the indicated genotypes were treated for $24 \mathrm{~h}$ with $0.5 \mathrm{~mm}$ glutamate and then stained by PI (red) to reveal cell death. Scale bar, $10 \mu \mathrm{m}$. B, The bar graph shows the number of PI-positive cells after treatment with 0.5 mm glutamate, expressed as a percentage of the untreated cells, which was determined in five fields for each sample group. Error bars show means \pm SEM ( $n=5$ independent experiments). The number of PI-positive cells was significantly higher in $\Delta$ CR cells than in controls. ${ }^{* *} p<0.01$, one-tailed Student's $t$ test. C, Differentiated NSCs of the indicated genotypes were treated for $24 \mathrm{~h}$ with $0.1 \mathrm{~mm}$ MK-801, $0.5 \mathrm{~mm}$ glutamate, or a mixture of the two, and then stained with PI to reveal cell death. The graph shows the number of PI-positive cells, expressed as a percentage of the untreated cells, determined in three fields for each sample group. Error bars show means \pm SEM ( $n=3$ independent experiments). The number of Pl-positive cells was significantly higher in $\Delta$ CR cultures treated with glutamate (red bar) compared with those cotreated with glutamate and MK-801 (red striped bar). * $p<0.01$, one-tailed Student's $t$ test.

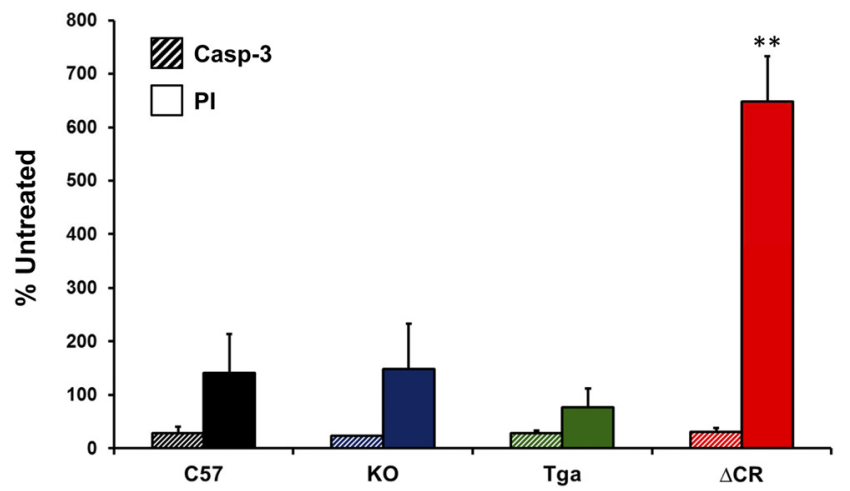

Figure 4. Cell death in glutamate-treated, $\Delta$ CR-expressing NSCs is not caspase-3 dependent. Differentiated NSCs of the indicated genotypes were treated for $24 \mathrm{~h}$ with $0.5 \mathrm{~mm}$ glutamate and then stained for activated caspase-3 (Casp-3) (striped bars) or PI (solid bars). The bar graph shows the number of positively stained cells, expressed as a percentage of the untreated cells, determined in three fields for each sample group. Error bars show means \pm SEM ( $n=3$ independent experiments). The number of PI-positive cells, but not the number of activated caspase 3-positive cells, was significantly higher in $\Delta$ CR cultures than in control cultures. ${ }^{* *} p<$ 0.01 , one-tailed Student's $t$ test.

the Tga20 transgene (Fig. $6 A-D$ ). These results demonstrate that, similar to cell lines expressing $\Delta \mathrm{CR} \operatorname{PrP}$, OCSs from $\Delta \mathrm{CR} / \mathrm{PrP} \mathrm{P}^{+/-}$ mice display hypersensitivity to Zeocin, an effect that can be rescued by the presence of WT PrP.

We reported previously that CGNs in $\operatorname{Tg}(\Delta \mathrm{CR})$ mice undergo a distinctive, non-apoptotic form of cell death that is morphologically and biochemically similar to that seen in certain types of glutamate excitotoxicity (Christensen et al., 2010). The most striking ultrastructural feature of dying neurons in $\operatorname{Tg}(\Delta \mathrm{CR})$ mice is a heterogeneous condensation of the nuclear matrix, which is distinct from discrete chromatin aggregates typical of classical apoptosis. To fur- ther validate OCS cultures as an experimental system to study the $\Delta \mathrm{CR}$ toxicity, we determined whether similar morphological features were seen in granule neurons in OCS preparations from $\operatorname{Tg}(\Delta \mathrm{CR})$ mice. Electron micrographs of $\Delta \mathrm{CR}$ OCSs prepared on P11 and kept in culture for 14 more days revealed granule neurons displaying marked condensation of the nuclear matrix (Fig. $7 B$ ), analogous to that observed in $\operatorname{Tg}(\Delta \mathrm{CR})$ mice. These neurons presumably correspond to the PI-positive granule neurons observed in untreated $\Delta$ CR slices (Fig. $6 A$ ). Conversely, no signs of nuclear condensation were detected in control slices (Fig. $7 A, C$ ). These results suggest that $\triangle \mathrm{CR}$ neurons die in a similar manner in $\mathrm{Tg}$ mice and slices and reinforce the idea that OCS cultures represent a reliable experimental system for studying $\Delta \mathrm{CR}$ toxicity.

\section{$\Delta$ CR-expressing OCSs are hypersensitive to glutamate-, NMDA-, and kainate-induced excitotoxicity}

To test whether OCSs from $\Delta \mathrm{CR} / \mathrm{Pr} P^{+/-}$mice are also hypersensitive to excitotoxic stimuli, we chronically exposed slices to 0.5 $\mathrm{mm}$ glutamate for $24 \mathrm{~h}$ and scored cell death by PI staining (Fig. $8 A$ ). We detected a markedly higher (more than twofold) percentage of PI-positive cells in $\Delta \mathrm{CR} / \mathrm{Pr} \mathrm{P}^{+/-}$OCSs compared with $\mathrm{PrP}^{+/-}$slices (Fig. 8B). PI-positive cells were almost exclusively localized in the cerebellar granule layer, consistent with the conclusion that glutamate induces excitotoxicity preferentially in $\Delta \mathrm{CR}$ PrP-expressing granule neurons and not in glia (Fig. 8A) [Purkinje cells do not express $\Delta \mathrm{CR}$ PrP, because the Tg vector lacks a Purkinje cell-specific enhancer (Li et al., 2007b)]. As expected, the hypersensitizing effect of the PrP mutant was fully abrogated in $\Delta \mathrm{CR} / \mathrm{Tga}$ slices. These data confirm that, as seen in NSCs, expression of $\Delta C R$ PrP enhances the susceptibility of neuronal cells to glutamate-induced excitotoxic stress.

To dissect the receptor specificity of glutamate-dependent cell death in $\Delta \mathrm{CR}$ neurons, we used specific agonists of different sub- 
types of ionotropic glutamate receptors, including NMDA, kainic acid, and AMPA. We exposed $\operatorname{PrP}^{+/-}, \Delta \mathrm{CR} /$ $\operatorname{Pr} P^{+/-}$, or $\Delta \mathrm{CR} / \mathrm{Tga}$ OCSs to NMDA, kainate, and AMPA and estimated the number of PI-positive granule neurons before and after treatment (Fig. 8C). We found that granule neurons in $\Delta \mathrm{CR} /$ $\mathrm{PrP}^{+/-}$OCSs were significantly more susceptible to both kainate and NMDA than those in $\mathrm{PrP}^{+/-}$or $\Delta \mathrm{CR} / \mathrm{Tga}$ control slices, with NMDA having a more marked effect. There was no significant difference between $\Delta \mathrm{CR} / \operatorname{Pr} \mathrm{P}^{+/-}$and control slices in their response to AMPA.

\section{Discussion}

One of the most puzzling questions in the field of prion diseases is how prions and other abnormal forms of PrP cause neurodegeneration (Mallucci, 2009). To address this question, we have been studying $\Delta \mathrm{CR} \operatorname{PrP}$, a deleted form of $\operatorname{PrP}$ that causes a lethal neurodegenerative phenotype when expressed in Tg mice. This phenotype is dose dependently suppressed by WT PrP, suggesting that the $\Delta \mathrm{CR}$ mutation subverts a normal, functional activity of $\operatorname{PrP}^{\mathrm{C}}$. We are interested in understanding the cellular pathways underlying the potent toxicity of $\Delta \mathrm{CR} \operatorname{PrP}$, with the expectation that these mechanisms will be relevant to naturally occurring prion disorders, such as those caused by dominantly inherited PrP mutations or infectious $\operatorname{PrP}{ }^{\mathrm{Sc}}$.

Previous studies of $\Delta C R$ PrP expressed in transfected cell lines revealed that this mutant induces large, spontaneous inward currents that can be recorded by whole-cell patch clamping and also hypersensitizes cells to the toxic effects of several cationic antibiotics, probably by facilitating drug entry (Massignan et al., 2010; Solomon et al., 2010b). Biophysical and cell biological analysis suggested that $\Delta C R \operatorname{PrP}$ currents are caused by formation of nonselective cationic channels in the plasma membrane and that the $\mathrm{N}$-terminal domain of PrP and attachment to the membrane are crucial for this activity (Solomon et al., 2010a, 2011). However, whether $\Delta$ CR PrP could exert these effects in neurons and cause neurotoxicity was unknown.

In this study, we demonstrate that $\Delta \mathrm{CR} \operatorname{PrP}$ induces spontaneous currents in neuronal cells from primary cultures and cerebellar slices. This activity, although insufficient by itself to induce extensive cell death, makes neurons unusually susceptible to glutamatedependent, $\mathrm{Ca}^{2+}$-mediated excitotoxicity. Importantly, WT PrP suppresses all these phenotypes, demonstrating a tight connection between the neurotoxicity of $\Delta C R \operatorname{PrP}$ and the physiological activity of $\operatorname{PrP}^{\mathrm{C}}$. Our results suggest a model in which $\Delta \mathrm{CR} \operatorname{PrP}$-induced current activity combines with endogenous, glutamate-mediated synaptic activity to unleash a $\mathrm{Ca}^{2+}$-dependent excitotoxic cascade, leading to neuronal death as observed in $\operatorname{Tg}(\Delta \mathrm{CR})$ mice. Because of the emerging role of $\mathrm{PrP}^{\mathrm{C}}$ as a receptor for oligomeric forms of the Alzheimer's $\mathrm{A} \beta$ peptide, and possibly other $\beta$-rich protein aggregates, our conclusions suggest that a similar PrP-dependent, excitotoxic mechanism may be operative in other neurodegenerative disorders.

\section{$\Delta$ CR PrP induces ionic currents in neurons}

To gain insights into the electrophysiological consequences of $\Delta$ CR PrP expression, we analyzed $\Delta$ CR-expressing neurons by whole-cell patch clamping. Our results show that $\Delta \mathrm{CR} \operatorname{PrP}$ generates spontaneous inward currents in CGNs in several different
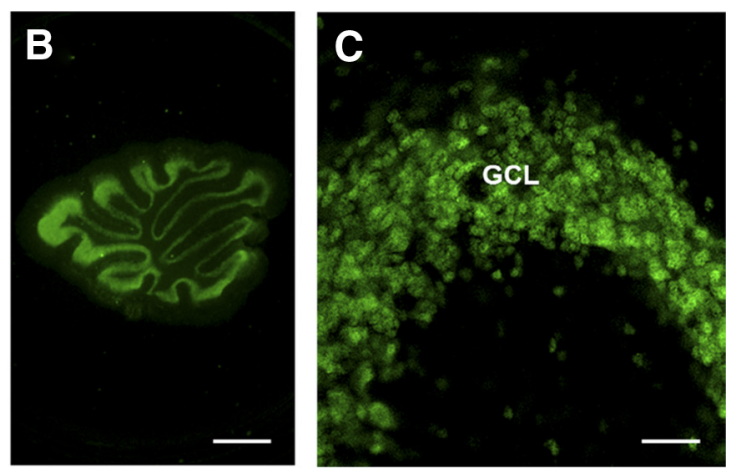

parations, including dissociated neurons that have been lentivirally transduced, as well as isolated neurons and cerebellar slices derived from $\operatorname{Tg}(\Delta \mathrm{CR})$ mice. These currents are similar in their properties to those we described in a variety of nonneuronal cell types, including those of mammalian and insect origin (Solomon et al., 2010b). Considering the wide variety of cell types in which $\triangle \mathrm{CR}$ currents have been observed, these data indicate either that mutant $\operatorname{PrP}$ molecules activate a ubiquitously expressed, endogenous ion channel or that the mutant protein itself forms pores in the cell membrane.

\section{Downstream pathways activated by $\Delta C R$ PrP}

How might the spontaneous current activity associated with $\Delta \mathrm{CR}$ PrP lead to the striking degeneration of CGNs observed in $\operatorname{Tg}(\Delta \mathrm{CR})$ mice? Several pieces of data have helped pinpoint downstream pathways that may be involved. In vivo, cell death occurring in $\Delta$ CR-expressing CGNs does not involve activation of caspase-3 or caspase- 8 (Li et al., 2007b; Christensen et al., 2010). Moreover, genetic deletion of the pro-apototic factor Bax had no effect on the disease progression or neuropathological signs in $\operatorname{Tg}(\Delta \mathrm{CR})$ mice (Li et al., 2007a). Consistent with these results, we failed to detect activated caspase-3 in $\Delta$ CR NSCs treated with glutamate. Collectively, our data indicate that neither the intrinsic nor extrinsic apoptotic pathways are involved in $\Delta \mathrm{CR}$ PrP-dependent neuronal loss. The possibility that $\Delta \mathrm{CR}$ CGNs die by an autophagic cell death pathway is also ruled out by the lack of increased LC3-II reactivity, a marker for autophagy, in the cerebellum of $\operatorname{Tg}(\Delta \mathrm{CR})$ mice (Christensen et al., 2010). Ultrastructural analyses further support these conclusions. In particular, degenerating granule neurons in $\operatorname{Tg}(\Delta \mathrm{CR})$ mice displayed a heterogeneous compaction of chromatin with preservation of the nuclear envelope, features distinct from neurons undergoing classical apoptosis (Christensen et al., 2010).

The distinctive ultrastructure of degenerating CGNs in $\operatorname{Tg}(\Delta \mathrm{CR})$ mice, which was also seen in the OSCs studied here (Fig. 7), is strikingly reminiscent of neurons undergoing excitotoxic death induced by the neurotransmitter glutamate (Christensen et al., 2010). This form of neuronal death is nonapoptotic and depends on activation of a pathway involving PARP-1 [poly(ADP-ribose) polymerase 1] and AIF (apoptosisinducing factor) (Yu et al., 2003). Thus, our data suggest that $\Delta \mathrm{CR}$ neurons degenerate by a non-apoptotic process that resembles glutamate-mediated excitotoxic death both biochemically and morphologically. 
A
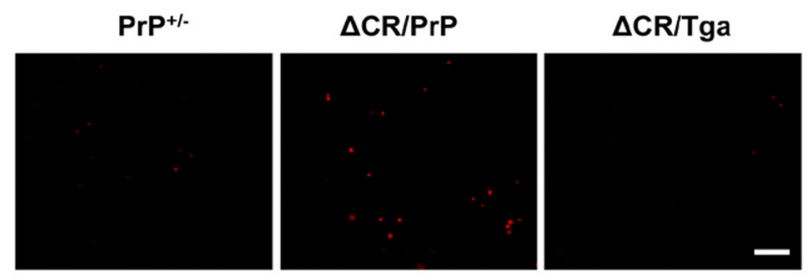

C

$\operatorname{PrP}+1-$

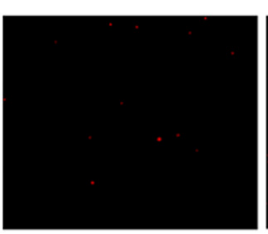

$\Delta C R / P r P$

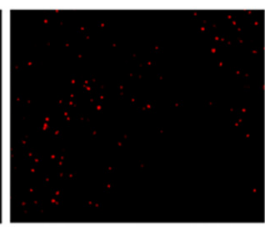

$\Delta \mathrm{CR} / \mathrm{Tga}$

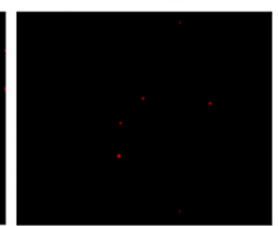

B

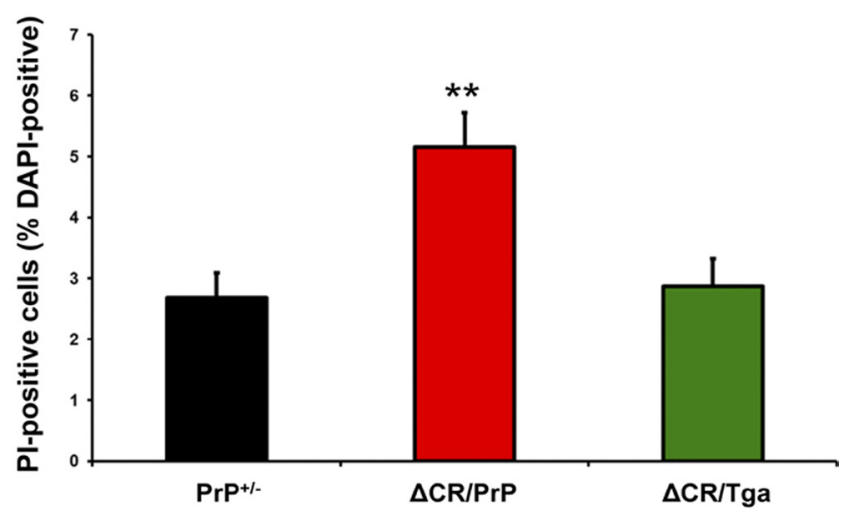

D

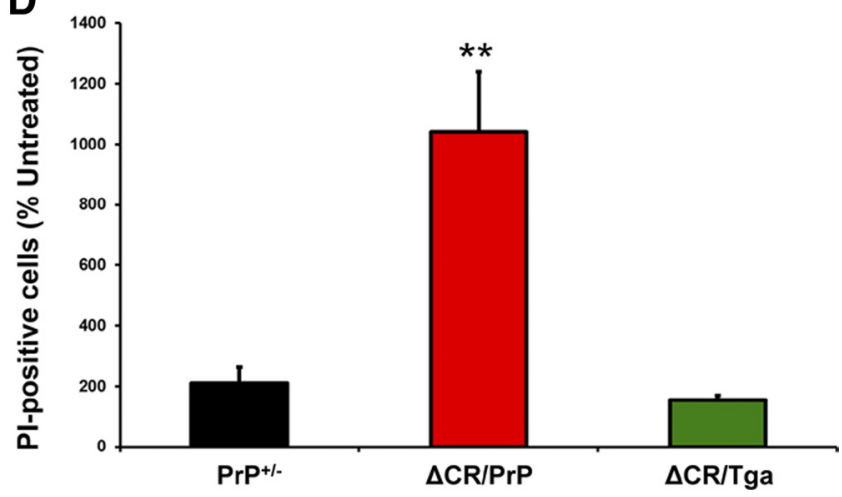

Figure 6. Granule neurons expressing $\Delta \mathrm{CR}$ PrP in cerebellar slices are hypersensitive to Zeocin. $A$, Pl labeling of slices obtained from $\Delta \mathrm{CR} / \operatorname{Pr} \mathrm{P}^{+/-}, \Delta \mathrm{CR} / \operatorname{Tga} 20^{+/-} / \operatorname{Pr} \mathrm{P}^{+/-}$, and $\mathrm{Pr} \mathrm{P}^{+/-}$ animals was evaluated $15 \mathrm{~d}$ after slices were placed in culture. $\boldsymbol{B}$, Quantitation of labeled cells (as a percentage of DAPI-positive nuclei) revealed a significant difference between untreated slices from $\Delta \mathrm{CR} / \mathrm{PrP}^{+/-}$and control animals. ${ }^{* *} p<0.01$. C, Pl labeling of slices treated with $500 \mu \mathrm{g} / \mathrm{ml}$ Zeocin for $24 \mathrm{~h}$ beginning on day 15 in culture. $D$, Quantitation of the proportion of labeled cells in Zeocin-treated slices (as a percentage of those in untreated slices) revealed a significant difference between $\Delta C \mathrm{R} / P r P^{+/-}$and control animals in Zeocin-induced toxicity. ${ }^{*} p<0.01$. Scale bars, $10 \mu \mathrm{m}$.

$\operatorname{PrP}^{+/-}$

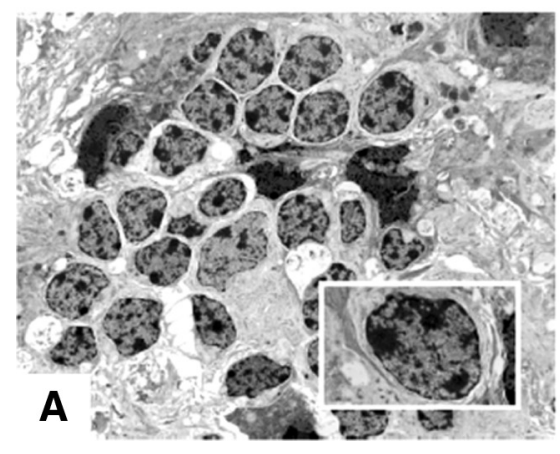

$\triangle \mathrm{CR} / \mathrm{PrP}$

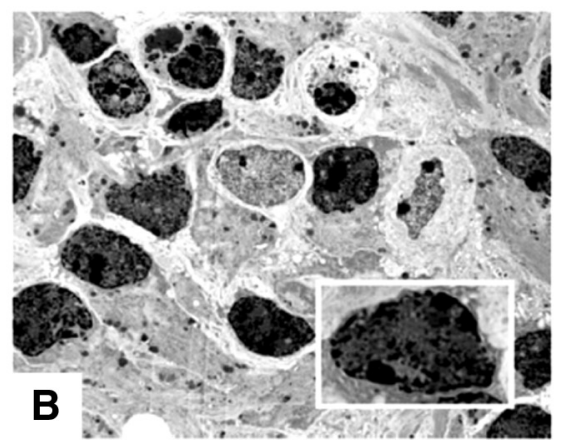

$\triangle \mathrm{CR} / \mathrm{Tga}$

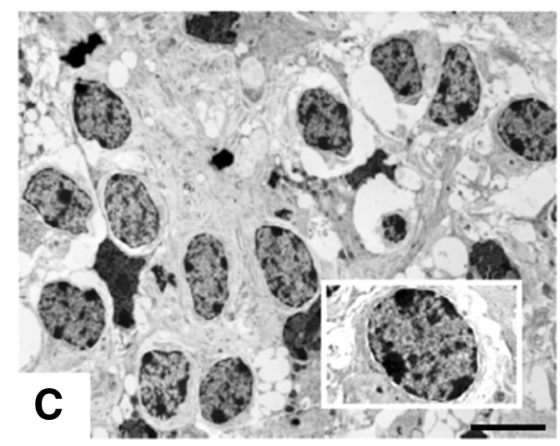

Figure 7. $\Delta C R$ neurons in cerebellar slices show ultrastructural features reminiscent of excitotoxic cell death. Electron micrographs of the cerebellar granule layer in slices cultures kept in culture for $15 \mathrm{~d}$ before fixing and embedding. Note the heterogeneously condensed chromatin in granule cell nuclei of $\Delta \mathrm{CR} / \mathrm{Pr}^{+/-}$mice $(\boldsymbol{B})$ that is not present in granule cell nuclei of $\mathrm{Pr} \mathrm{P}^{+/-}(\boldsymbol{A})$ or $\Delta \mathrm{CR} / \mathrm{Tga}^{+/-} / \mathrm{PrP}^{+/-}(\mathrm{C})$ animals (see insets). Scale bar, $2 \mu \mathrm{m}$.

A role for glutamate in $\Delta \mathrm{CR}$ PrP-dependent neuronal death We present here several different experiments that directly implicate glutamate-mediated excitotoxicity in the neuronal death caused by $\Delta \mathrm{CR}$ PrP. First, we observed that expression of $\Delta \mathrm{CR}$ $\mathrm{PrP}$ induced neuron-specific, $\mathrm{Ca}^{2+}$-mediated hypersensitivity to glutamate stimulation in differentiated NSCs. This phenomenon, which was characterized by a higher amount of $\mathrm{Ca}^{2+}$ influx and a slower rate of intracellular $\mathrm{Ca}^{2+}$ recovery in $\Delta \mathrm{CR} \operatorname{PrP}-$ expressing neurons compared with control neurons was accom- panied by increased neuronal death in cultures that were chronically treated with glutamate. $\triangle$ CR neurons in OCS cultures were also highly susceptible to glutamate-induced cell death. When treated with different glutamate agonists, these cells showed a pattern of sensitivity $(\mathrm{NMDA}>$ kainate $>$ AMPA) that paralleled the ability of each agonist to induce $\mathrm{Ca}^{2+}$ influx. Consistently, hypersusceptibility to glutamate treatment of $\Delta \mathrm{CR}$ NSCs was abrogated by interfering with the activation of NMDA receptors. Together, these results provide strong support for the 
A

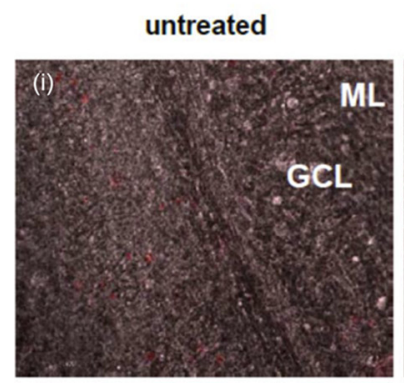

$500 \mu \mathrm{M}$ Glutamate

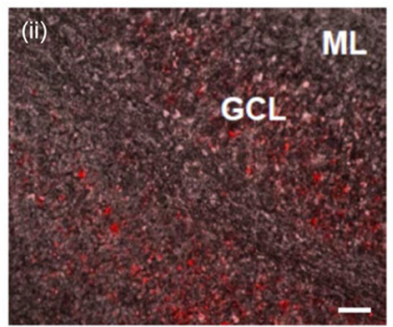

B

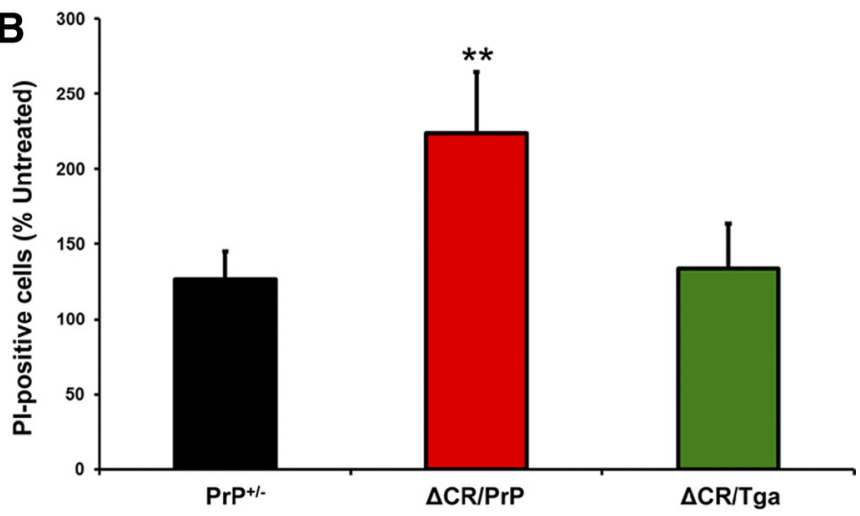

C

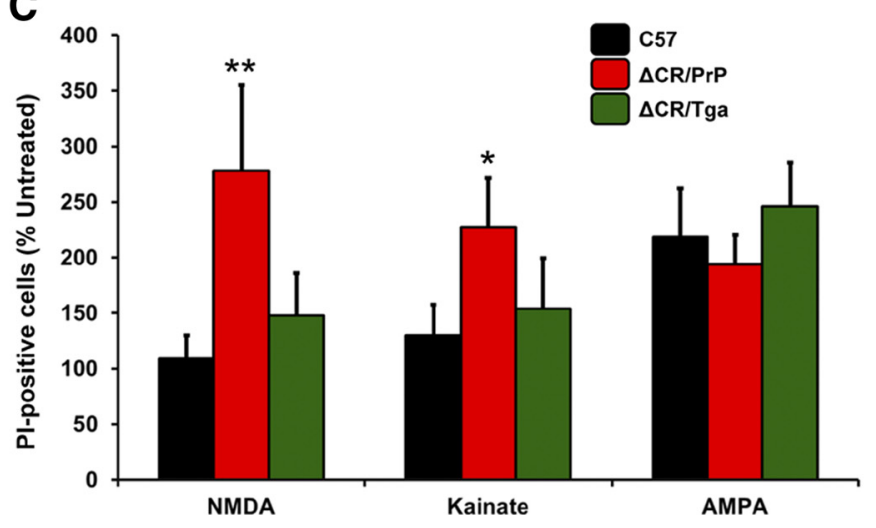

Figure 8. $\Delta C$ R granule neurons in cerebellar slices are hypersensitive to glutamate, NMDA, and kainate. $A$, PI labeling of slices after treatment with $500 \mu \mathrm{m}$ glutamate for $24 \mathrm{~h}$ shows that cells within the cerebellar granule cell layer of $\Delta \mathrm{CR} / \mathrm{Pr}^{+} \mathrm{P}^{+-}$animals are significantly more susceptible to glutamate-induced toxicity than controls. Overlay of bright-field images and PI fluorescence images confirms that the dying cells localize to the granule cell layer. Scale bar, $20 \mu \mathrm{m}$. B, Quantitation of labeled cells revealed significant differences in glutamate-induced toxicity between $\Delta \mathrm{CR} / \mathrm{PrP}^{+/-}$animals and controls. ${ }^{* *} \mathrm{p}<0.01$. C, Quantitation of PI-positive cells after treatment with receptor subtype agonists reveals that $\Delta \mathrm{CR} / \mathrm{PrP}{ }^{+/-}$slices contain significantly more labeled cells compared with controls after treatment with NMDA and kainate but not AMPA. ${ }^{*} p<0.05,{ }^{* *} p<0.01$. ML, Molecular layer; GCL, granule cell layer.

notion that expression of $\Delta \mathrm{CR} \operatorname{PrP}$ sensitizes neuronal cells to glutamate-induced, $\mathrm{Ca}^{2+}$-mediated excitotoxicity.

\section{How does $\Delta$ CR PrP enhance glutamate sensitivity?}

One possible explanation for our data is that $\Delta \mathrm{CR}$ PrP directly activates endogenous, ionotropic glutamate receptors in neurons. $\operatorname{PrP}^{\mathrm{C}}$ was reported previously to suppress the activity of NMDA receptors through a direct interaction with NR2D subunits, thereby protecting neurons from glutamate excitotoxicity (Khosravani et al., 2008; Stys et al., 2012; You et al., 2012). In addition, increased kainate-dependent neuronal death was observed in mice lacking $\operatorname{PrP}^{\mathrm{C}}$ (Rangel et al., 2007). We report here that WT PrP fully rescues $\Delta$ CR PrP-induced hypersensitivity to glutamate in differentiated NSCs and OCS cultures. These results suggest that $\triangle \mathrm{CR} \operatorname{PrP}$, instead of silencing NMDA receptors like WT PrP, activates them, possibly via a physical interaction with NR2D or other channel subunits. Alternatively, $\Delta$ CR PrP could also directly or indirectly affect the activity of other ion channels, such as nAChRs (Petrakis et al., 2008; Beraldo et al., 2010), to increase neuronal excitability. A number of electrophysiological abnormalities have been reported in neurons from PrP KO mice (Linden et al., 2008), suggesting that $\operatorname{PrP}^{\mathrm{C}}$ might normally modulate several kinds of ion channels, a function that could be corrupted by $\Delta$ CR or other central region mutations.

In our initial characterization of $\Delta \mathrm{CR}$-associated currents, we reported a lack of inhibitory effect of different ion channel blockers, including tetraethylammonium, tetrodotoxin, and MK-801 (blockers of voltage-gated potassium channels, voltage-gated so- dium channels, and NMDA receptors, respectively) (Solomon et al., 2010a). In the same study, we also showed that $\Delta$ CR currents can be detected in a variety of cell lines, including HEK293 and Sf9 cells. These latter cell lines are known to have limited expression of endogenous ion channels, including undetectable levels of NMDA receptors (Larsen et al., 1996; Thomas and Smart, 2005). Moreover, the presence of $\Delta \mathrm{CR}$ currents in cell types from evolutionary distant species (HEK293 are a human cell line, whereas Sf9 are insect cells) suggests that any channel involved in mediating the currents of mutant PrP must be highly conserved across cell types and species. There are examples of such channels, such as connexin (gap junction) or pannexin hemichannels, but it remains to be determined whether such channels play a role in $\Delta$ CR PrP-induced currents.

An alternative model is based on the idea that the $\Delta \mathrm{CR} \operatorname{PrP}$ itself forms an ion channel or pore in the cell membrane. In this scenario, the spontaneous current activity induced by $\Delta \mathrm{CR} \operatorname{PrP}$ is insufficient on its own to cause significant neuronal death, but it primes the neuron to degenerate in response to endogenous synaptic inputs such as those mediated by glutamate. This model is consistent with the striking observation that, although $\Delta \mathrm{CR} \operatorname{PrP}$ induces massive death of CGNs in $\operatorname{Tg}(\Delta \mathrm{CR})$ mice, expression of the mutant protein has minimal effect on the viability of neurons in differentiated stem cell cultures (Massignan et al., 2010) and cerebellar slices (Fig. $6 A, B$ ), situations in which these neurons are deprived of their normal synaptic input. During normal cerebellar development, CGNs receive excitatory glutamatergic input from mossy fibers at the time they complete their migration from 
the external to the internal granule layer (Kandel, 2012). Consistent with this timeline, we observed that granule cell degeneration in $\operatorname{Tg}(\Delta \mathrm{CR})$ mice is absent from the external layer and occurs in a highly synchronous manner in the internal layer at P13-P15 in $\mathrm{Tg}(\Delta \mathrm{CR}) / \mathrm{Prn}-\mathrm{p}^{+/-}$mice, coincident with mossy fiber innervation (Christensen et al., 2010). Moreover, our patch-clamping analyses of acute cerebellar slices revealed an unexpected fragility of $\Delta \mathrm{CR}$ granule neurons. This phenomenon, although difficult to dissect experimentally, indicates that $\Delta \mathrm{CR} \operatorname{PrP}$ is deleterious to the integrity of the neuronal plasma membrane and may prime neurons to degenerate in response to increased levels of endogenous synaptic activity or perhaps other physiological stresses.

As mentioned above, it was reported previously that WT neurons were less susceptible to glutamate-induced excitotoxicity than neurons from PrP-null mice (Khosravani et al., 2008). These data apparently conflict with our observation that NSCs lacking $\operatorname{PrP}^{\mathrm{C}}$ do not show higher sensitivity to glutamate treatment than control NSCs (Figs. 2, 3). However, the discrepancy may easily be related to the use of different experimental models (differentiated NSCs vs primary neuronal cultures) or to the strain background of the mice used for the experiments.

\section{Relevance for prion diseases and other neurodegenerative disorders}

Recent evidence that $\operatorname{PrP}^{\mathrm{C}}$ binds to $\mathrm{A} \beta$ oligomers and other misfolded protein isoforms suggests that the underlying mechanism for several neurodegenerative disorders may converge on $\operatorname{PrP}^{\mathrm{C}}$ (Biasini et al., 2012a). We hypothesized that binding of several oligomeric protein assemblies, including $\operatorname{PrP}^{\mathrm{Sc}}$ and $\mathrm{A} \beta$ oligomers, causes a conformational change in the $\operatorname{PrP}^{\mathrm{C}}$ molecule, with consequent insertion of its $\mathrm{N}$-terminal polybasic domain across the membrane and generation of " $\Delta \mathrm{CR}$-like" channels or pores (Solomon et al., 2012). Deletions within the central region of PrP would constitutively induce such a topological change and produce the strongest channel activity. In support of this model, the same two regions on $\operatorname{PrP}$ that determine $\Delta \mathrm{CR} \operatorname{PrP}$ channel activity (residues 23-31 and 105-125) overlap with or are adjacent to regions involved in binding of $\operatorname{PrP}^{\mathrm{C}}$ to $\operatorname{PrP}^{\mathrm{Sc}}, \mathrm{A} \beta$ oligomers, and other $\beta$-rich aggregates. Based on the results presented here, we suggest that other oligomeric protein assemblies might sensitize neurons to glutamate-mediated excitotoxicity via a $\operatorname{PrP}^{\mathrm{C}}$ dependent mechanism. If so, then glutamate channel blockers, as well as drugs that prevent binding of $\beta$-sheet-rich oligomers to $\operatorname{PrP}^{\mathrm{C}}$ or that block the conformational transition of $\operatorname{PrP}^{\mathrm{C}}$ may show therapeutic benefits for several neurodegenerative diseases (Biasini and Harris, 2012). Indeed, memantine, a glutamate channel blocker, is currently used for treatment of Alzheimer's disease (Maggiore et al., 2007).

\section{References}

Aguzzi A, Heikenwalder M, Polymenidou M (2007) Insights into prion strains and neurotoxicity. Nat Rev Mol Cell Biol 8:552-561. CrossRef Medline

Balducci C, Beeg M, Stravalaci M, Bastone A, Sclip A, Biasini E, Tapella L, Colombo L, Manzoni C, Borsello T, Chiesa R, Gobbi M, Salmona M, Forloni G (2010) Synthetic amyloid-beta oligomers impair long-term memory independently of cellular prion protein. Proc Natl Acad Sci U S A 107:2295-2300. CrossRef Medline

Beraldo FH, Arantes CP, Santos TG, Queiroz NG, Young K, Rylett RJ, Markus RP, Prado MA, Martins VR (2010) Role of alpha7 nicotinic acetylcholine receptor in calcium signaling induced by prion protein interaction with stress-inducible protein 1. J Biol Chem 285:36542-36550. CrossRef Medline

Biasini E, Harris DA (2012) Targeting the cellular prion protein to treat neurodegeneration. Future Med Chem 4:1655-1658. CrossRef Medline
Biasini E, Turnbaugh JA, Unterberger U, Harris DA (2012a) Prion protein at the crossroads of physiology and disease. Trends Neurosci 35:92-103. CrossRef Medline

Biasini E, Turnbaugh JA, Massignan T, Veglianese P, Forloni G, Bonetto V, Chiesa R, Harris DA (2012b) The toxicity of a mutant prion protein is cell-autonomous, and can be suppressed by wild-type prion protein on adjacent cells. PLoS One 7:e33472. CrossRef Medline

Brandner S, Isenmann S, Raeber A, Fischer M, Sailer A, Kobayashi Y, Marino S, Weissmann C, Aguzzi A (1996) Normal host prion protein necessary for scrapie-induced neurotoxicity. Nature 379:339-343. CrossRef Medline

Büeler H, Fischer M, Lang Y, Bluethmann H, Lipp HP, DeArmond SJ, Prusiner SB, Aguet M, Weissmann C (1992) Normal development and behavior of mice lacking the neuronal cell-surface PrP protein. Nature 356:577-582. CrossRef Medline

Caughey B, Baron GS (2006) Prions and their partners in crime. Nature 443:803-810. CrossRef Medline

Chen S, Yadav SP, Surewicz WK (2010) Interaction between human prion protein and amyloid-beta (Abeta) oligomers: role OF N-terminal residues. J Biol Chem 285:26377-26383. CrossRef Medline

Chesebro B, Trifilo M, Race R, Meade-White K, Teng C, LaCasse R, Raymond L, Favara C, Baron G, Priola S, Caughey B, Masliah E, Oldstone M (2005) Anchorless prion protein results in infectious amyloid disease without clinical scrapie. Science 308:1435-1439. CrossRef Medline

Christensen HM, Harris DA (2009) A deleted prion protein that is neurotoxic in vivo is localized normally in cultured cells. J Neurochem 108:44-56. CrossRef Medline

Christensen HM, Dikranian K, Li A, Baysac KC, Walls KC, Olney JW, Roth KA, Harris DA (2010) A highly toxic cellular prion protein induces a novel, nonapoptotic form of neuronal death. Am J Pathol 176:2695-2706. CrossRef Medline

Fischer M, Rülicke T, Raeber A, Sailer A, Moser M, Oesch B, Brandner S, Aguzzi A, Weissmann C (1996) Prion protein (PrP) with aminoproximal deletions restoring susceptibility of PrP knockout mice to scrapie. EMBO J 15:1255-1264. Medline

Forloni G, Lucca E, Angeretti N, Chiesa R, Vezzani A (1997) Neuroprotective effect of somatostatin on nonapoptotic NMDA-induced neuronal death: role of cyclic GMP. J Neurochem 68:319-327. CrossRef Medline

Gunther EC, Strittmatter SM (2010) Beta-amyloid oligomers and cellular prion protein in Alzheimer's disease. J Mol Med (Berl) 88:331-338. CrossRef Medline

Harris DA, True HL (2006) New insights into prion structure and toxicity. Neuron 50:353-357. CrossRef Medline

Kandel ER (2012) Principles of neural science, Ed 5. New York: McGrawHill.

Khosravani H, Zhang Y, Tsutsui S, Hameed S, Altier C, Hamid J, Chen L, Villemaire M, Ali Z, Jirik FR, Zamponi GW (2008) Prion protein attenuates excitotoxicity by inhibiting NMDA receptors. J Cell Biol 181:551565. CrossRef Medline

Larsen EH, Gabriei SE, Stutts MJ, Fullton J, Price EM, Boucher RC (1996) Endogenous chloride channels of insect sf9 cells. Evidence for coordinated activity of small elementary channel units. J Gen Physiol 107:695714. CrossRef Medline

Laurén J, Gimbel DA, Nygaard HB, Gilbert JW, Strittmatter SM (2009) Cellular prion protein mediates impairment of synaptic plasticity by amyloid-beta oligomers. Nature 457:1128-1132. CrossRef Medline

Li A, Barmada SJ, Roth KA, Harris DA (2007a) N-terminally deleted forms of the prion protein activate both Bax-dependent and Bax-independent neurotoxic pathways. J Neurosci 27:852-859. CrossRef Medline

Li A, Christensen HM, Stewart LR, Roth KA, Chiesa R, Harris DA (2007b) Neonatal lethality in transgenic mice expressing prion protein with a deletion of residues 105-125. EMBO J 26:548-558. CrossRef Medline

Linden R, Martins VR, Prado MA, Cammarota M, Izquierdo I, Brentani RR (2008) Physiology of the prion protein. Physiol Rev 88:673-728. CrossRef Medline

Maggiore C, Locatelli L, Grandi FC, Pizzolato G (2007) Memantine in the treatment of dementia. Neuroepidemiology 28:118-119. CrossRef Medline

Mallucci G, Dickinson A, Linehan J, Klöhn PC, Brandner S, Collinge J (2003) Depleting neuronal $\operatorname{PrP}$ in prion infection prevents disease and reverses spongiosis. Science 302:871-874. CrossRef Medline 
Mallucci GR (2009) Prion neurodegeneration: starts and stops at the synapse. Prion 3:195-201. CrossRef Medline

Mallucci GR, White MD, Farmer M, Dickinson A, Khatun H, Powell AD, Brandner S, Jefferys JG, Collinge J (2007) Targeting cellular prion protein reverses early cognitive deficits and neurophysiological dysfunction in prion-infected mice. Neuron 53:325-335. CrossRef Medline

Martin JH (1996) Neuroanatomy: text and atlas, Ed 2. Stamford, CT: Appleton and Lange.

Massignan T, Stewart RS, Biasini E, Solomon IH, Bonetto V, Chiesa R, Harris DA (2010) A novel, drug-based, cellular assay for the activity of neurotoxic mutants of the prion protein. J Biol Chem 285:7752-7765. CrossRef Medline

Michaelis EK (1998) Molecular biology of glutamate receptors in the central nervous system and their role in excitotoxicity, oxidative stress and aging. Prog Neurobiol 54:369-415. CrossRef Medline

Petrakis S, Irinopoulou T, Panagiotidis CH, Engelstein R, Lindstrom J, OrrUrtreger A, Gabizon R, Grigoriadis N, Sklaviadis T (2008) Cellular prion protein co-localizes with $\mathrm{nAChR}$ beta4 subunit in brain and gastrointestinal tract. Eur J Neurosci 27:612-620. CrossRef Medline

Rangel A, Burgaya F, Gavín R, Soriano E, Aguzzi A, Del Río JA (2007) Enhanced susceptibility of Prnp-deficient mice to kainate-induced seizures, neuronal apoptosis, and death: role of AMPA/kainate receptors. J Neurosci Res 85:2741-2755. CrossRef Medline

Resenberger UK, Harmeier A, Woerner AC, Goodman JL, Müller V, Krishnan R, Vabulas RM, Kretzschmar HA, Lindquist S, Hartl FU, Multhaup G, Winklhofer KF, Tatzelt J (2011) The cellular prion protein mediates neurotoxic signalling of beta-sheet-rich conformers independent of prion replication. EMBO J 30:2057-2070. CrossRef Medline
Solomon IH, Schepker JA, Harris DA (2010a) Prion neurotoxicity: insights from prion protein mutants. Curr Issues Mol Biol 12:51-61. Medline

Solomon IH, Huettner JE, Harris DA (2010b) Neurotoxic mutants of the prion protein induce spontaneous ionic currents in cultured cells. J Biol Chem 285:26719-26726. CrossRef Medline

Solomon IH, Khatri N, Biasini E, Massignan T, Huettner JE, Harris DA (2011) An N-terminal polybasic domain and cell surface localization are required for mutant prion protein toxicity. J Biol Chem 286: 14724-14736. CrossRef Medline

Solomon IH, Biasini E, Harris DA (2012) Ion channels induced by the prion protein: mediators of neurotoxicity. Prion 6:40-45. CrossRef Medline

Stys PK, You H, Zamponi GW (2012) Copper-dependent regulation of NMDA receptors by cellular prion protein: implications for neurodegenerative disorders. J Physiol 590:1357-1368. CrossRef Medline

Thomas P, Smart TG (2005) HEK293 cell line: a vehicle for the expression of recombinant proteins. J Pharmacol Toxicol Methods 51:187-200. CrossRef Medline

White MD, Farmer M, Mirabile I, Brandner S, Collinge J, Mallucci GR (2008) Single treatment with RNAi against prion protein rescues early neuronal dysfunction and prolongs survival in mice with prion disease. Proc Natl Acad Sci U S A 105:10238-10243. CrossRef Medline

You H, Tsutsui S, Hameed S, Kannanayakal TJ, Chen L, Xia P, Engbers JD, Lipton SA, Stys PK, Zamponi GW (2012) Abeta neurotoxicity depends on interactions between copper ions, prion protein, and $N$-methyl-Daspartate receptors. Proc Natl Acad Sci U S A 109:1737-1742. CrossRef Medline

Yu SW, Wang H, Dawson TM, Dawson VL (2003) Poly(ADP-ribose) polymerase-1 and apoptosis inducing factor in neurotoxicity. Neurobiol Dis 14:303-317. CrossRef Medline 